\title{
Pulling the Trigger: How Threats to the Nation Increase Support for Military Action via the Generation of Hubris
}

\author{
Yuval Feinstein
}

University of Haifa

Abstract: Previous studies of public opinion in the United States have reported positive associations between national hubris and support for military actions. This article argues that in addition to its stable aspect, national hubris has a contextual aspect: under perceived symbolic threats to the nation, national hubris increases and boosts support for military action. To test this argument, which is grounded in a sociological and social psychological understanding of individuals as members of collectivities who pursue a symbolic politics of status achievement and maintenance, a surveyexperiment was conducted with a nationally representative sample. In the experiment, participants who were exposed to rhetoric that highlighted symbolic threats to the nation to justify an impending military action against Iran's nuclear facilities reported higher levels of national hubris and were more likely to support the military action than either participants who were exposed to internationalist rhetoric or those in the control group.

Keywords: nationalism; war; public opinion; survey-experiment

Citation: Feinstein, Yuval. 2016. "Pulling the Trigger: How Threats to the Nation Increase Support for Military Action via the Generation of Hubris." Sociological Science 3: 317-334.

Received: January 4, 2016

Accepted: February 8, 2016

Published: May 25, 2016

Editor(s): Jesper Sørensen, Sarah Soule

DOI: $10.15195 /$ v3.a15

Copyright: (C) 2016 The Author(s). This open-access article has been published under a Creative Commons Attribution License, which allows unrestricted use, distribution and reproduction, in any form, as long as the original author and source have been credited. (0)(1)
$\mathrm{T}^{\mathrm{N}}$ the United States, as in other democratic countries, the ability to pursue war 1 efforts abroad depends on gaining support at home; therefore, there is considerable academic and political interest in the question of what motivates U.S. citizens to support the use of military power. Surprisingly, the existing literature on public attitudes largely overlooks the role of popular nationalism as well as the specific ties between this diffuse sentiment and support for military actions. ${ }^{1}$ This article argues that individuals support the use of military power when official rhetoric about an international conflict activates national hubris- the belief in the special virtue of the nation and the superiority of its state. The article discusses the results of a survey-experiment that tested my argument. In the experiment, individuals in a representative sample of adults in the United States were exposed to different official framings of a plan to use military force to attack nuclear facilities in Iran. The results show that when official rhetoric triggers a sentiment of national superiority (henceforth "national hubris"), the level of support for military action increases.

\section{Theoretical Framework and Hypotheses}

\section{Nationalism and Support for Military Actions}

In contrast to the dominant tradition in nationalism research, which focuses on the essential elements of each country's national identity (e.g., Kohn 1944; Lipset 1990), cultural sociologists and political psychologists maintain that different ideas and 
symbols compose the national self-understanding of individuals who are considered members of one nation (Bonikowski and DiMaggio, forthcoming; Brubaker 2004; Schildkraut 2011). To analyze the complex nature of nationalism, studies have developed multidimensional measures that use a distinct set of survey items to assess each aspect of nationalism, distinguishing, for example, between attachment to the nation, cultural conception of the nation, and belief in the superiority of the nation (Herrmann, Iserina, and Segatti 2009; see also Huddy and Khatib 2007; Dekker, Malova, and Hoogendoorn 2003). Most importantly, studies have shown that political attitudes can be associated with certain dimensions of nationalism but not related to others. Specifically, militant positions about foreign affairs and intolerance toward minority groups within the country are associated with chauvinist and ethnocentric views of the nation but are not significantly associated with either the salience of national identities or the strength of individual attachments to the nation-state (de Figueiredo and Elkins 2003; Kosterman and Feshbach 1989; Worchel and Coutant 1997).

Following Kosterman and Feshbach's (1989) seminal study on the differences between "nationalism" (i.e., national chauvinism) and "patriotism" (love of and pride in the country), political psychologists often explain that national chauvinism is accompanied by a desire to dominate other nations (e.g., de Figueiredo and Elkins 2003; Huddy and Khatib 2007). However, these scholars rarely explain what a desire to dominate other nations actually entails for public opinion about foreign affairs. Herrmann and coauthors (2009) are an important exception: they explain that feelings of national superiority lead individuals to have "an expectation that international relations should be governed by a norm of authority ranking with their nation on top" (p. 729), which, during international conflicts, means that they expect opponents to succumb to the demands of "our" government, even if this requires the use of military force against defiant enemies. ${ }^{2}$

Most researchers view national hubris as a fixed bias (Druckman et al. 2006). In contrast, this article proposes that the level of national hubris depends, to some extent, on the situation. Certain stimuli may strengthen the national hubris experienced by an individual, which in turn influences the individual's foreign policy preferences. This expectation is in line with an often-overlooked comment in the conclusion of Kosterman and Feshbach's (1989) frequently cited article: "One cannot help but be concerned by the periodic waves of nationalism [i.e., national chauvinism] that seem to sweep nations and the accompanying receptivity to belligerent actions." (P. 273)

What could cause an increase in national hubris that would then lead to increased support for military action? Previous studies have shown that, in the United States, the use of force becomes popular when presidential rhetoric creates a widespread concern for national security (Kaufmann 2004; Nincic 1997; Willer 2004). I argue that concerns for national security generate militant attitudes through a process of national identification, in which the specific mediating mechanism is national hubris that emerges due to perceived competition with national "others." This argument is grounded in a fundamental principle of how individuals behave as members of groups: as shown in numerous social psychology experiments, individuals tend to display a positive bias toward their ingroup and negative atti- 
tudes toward outgroups when they sense a threat to their group or competition by outgroups (for a review, see Ellemers, Spears, and Doosje 2002).

Importantly, concerns about national security are sociotropic concerns (Huddy et al. 2005) that center on the national group (as opposed to personal security). In the United States, which usually fights its wars abroad against militarily weaker enemies, concerns about national security center on symbolic threats to national honor and to the country's special international status. For example, Snyder and Borghard's (2011) investigation of public reactions to the threats issued by U.S. administrations during international crises between 1945 and 1994 demonstrates that, more than any other aspect of international conflicts, individual-level desires to maintain both national honor and an international reputation for resolve influence public opinion in the United States.

These findings are in line with the sociological view of nations as status groups: membership in the nation is a subjective experience that, although not promising equal access to material and political resources, nevertheless offers all members a shared symbolic resource: the nation's prestige (Finlayson 1998). Because an individual's own sense of self-worth is often closely tied to the prestige of the nation (Greenfeld 2006; Elias [1956] 1998:89), many individuals make a profound commitment to the nation and the protection of its prestige (Greenfeld 2006; McLaughlin 1996). Consequently, the propagation of symbolic threats is a powerful tool in the hands of public opinion leaders. A comparative-historical investigation of public opinion formation in the United States during all major war events and security crises since the Second World War (Feinstein, forthcoming) reveals that when presidents successfully mobilized the public to "rally around the flag," they did not simply highlight security threats but also emphasized the cultural virtue of the United States, stressed that the enemy had defied U.S. authority, and called on Americans to remain determined and stand firm for their common values in face of the defiance. I speculated that in these historical cases, presidential rhetoric mobilized public opinion because it triggered national hubris. The main goal of the present study is to test whether increased national hubris does indeed mediate the effects of official rhetoric highlighting threats to national security and confrontation with a defiant enemy on support for military action.

\section{Methods}

Empirical studies of attitudinal dispositions face considerable challenges, because dispositions are obscure- "like a soldier's courage in the absence of war" (Bourdieu 2000:149)—and only reveal themselves in situ. I designed a survey-based experiment to analyze some of the dispositions embedded in a nationalist outlook.

\section{The Setting}

The external validity of experiments depends not only on having a representative sample but also on creating a setting in which the behavior of participants can be considered an instance of their behavior in the "real world" (Zelditch 2007). In experiments that investigate the formation of political attitudes, the situations to 
which participants are asked to respond should not only be plausible but must also be perceived by the participants as real (Brader 2006). This need for realism is one of the major challenges in studies of public attitudes in response to crisis situations. Past studies have sought to address this challenge by asking respondents to imagine a plausible situation (e.g., Brooks and Valentino 2011); however, participants might have been influenced by their awareness that the situation was not actually occurring. The present study, in contrast, addressed this challenge by investigating individuals' reactions to information about an ongoing major international crisis that had the potential to deteriorate into a military confrontation: the international crisis related to the Iranian nuclear program. Although no military attack had been launched on the nuclear facilities in Iran at the time of the study, such an attack was a realistic possibility. While this experimental setting cannot completely eliminate the problem of external validity (see the discussion of limitations in the conclusion), it is a significant improvement over previous methodologies.

\section{Experimental Design}

The experiment involved two steps. First, respondents who had been assigned to one of two test groups were asked to listen to a recorded statement, which was presented as a transcript of a forthcoming policy statement by President Obama that had been leaked to the press. ${ }^{3}$ The statement explained why the United States should use its airpower to attack Iran if the Iranian government did not comply with a one-month ultimatum to halt its nuclear program.

In light of my theoretical framework, I expected that rhetoric highlighting threats to the nation from a defiant enemy and proposing a military reaction would function as an effective trigger of national hubris and that the activation of national hubris would lead to increased support of the military operation. To test these expectations, the study employed two versions of the policy statement. The first version justified the military operation in Iran by highlighting threats to the American nation and to the United States: the statement maintained that the Iranian government was controlled by Islamic extremists who hated the United States and its values, stressed that the Iranian nuclear program posed a threat to the United States, and called on the American people to unite behind an ultimatum that the president had issued to Iran and support an expected air strike by the U.S. Air Force. In contrast, the second version of the statement presented an internationalist framework: the statement announced that the United Nations (UN) Security Council had issued an ultimatum to Iran and, if the ultimatum was not met, a coalition air strike against Iran would follow. Accordingly, the expected military involvement of the United States was presented as meeting the country's obligation as a member of the UN Security Council and as fulfilling the country's commitment to protect human rights and advance world peace. Table 1 presents full transcripts of the statements.

One-third of the sample was assigned to a control group. In this group, participants were told that the president was about to announce an ultimatum to Iran to stop its nuclear program within one month and that, if Iran failed to comply, an air strike would be launched on its nuclear sites. Participants in the control group were offered no information as to whether the ultimatum was issued by the United 
Table 1: Transcripts of Presidential Statements

Nationalist statement

"In the last five years, the United States has tried to bring Iran's nuclear project to a halt. However, seemingly endless diplomatic efforts and economic sanctions have proven useless and nuclear reactors are being built in Iran as we speak. New evidence acquired by the CIA proves that Iran is on the verge of building a nuclear arsenal.

Iran is controlled by Islamic extremists who hate America because of the values our country represents: freedom and equal opportunities for men and women, and for people of all religions.

For years, Iran has funded and trained terrorist groups who operate against the United States. American intelligence agencies have warned that Iran still sponsors al-Qaeda and other terrorist groups, including Hamas and Hezbollah, that are actively planning attacks on American targets. A nuclear Iran will be a threat to the United States.

Because diplomacy and economic sanctions have failed to put an end to Iran's nuclear ambitions, America will have no choice but to use its military power unless the regime immediately dismantles its nuclear program and allows verification by American inspectors.

Today, I am giving an ultimatum to the Iranian government: stop the construction of nuclear facilities immediately or face military consequences. We will allow Iran one month: if by the end of this term our demand is not met, we will use U.S. airpower to destroy all nuclear facilities in Iran.

To the American people I say this: We are not choosing this confrontation with Iran. Rather, it has been imposed upon us by Iran's adversarial behavior. America cannot be blackmailed or outmaneuvered by deception and threat. Standing together firmly and faithful to our principles, we will prevail.

God bless you, and God bless the United States of America."
Internationalist statement

"In the last five years, the international community has tried to bring Iran's nuclear project to a halt. However, seemingly endless diplomatic efforts and economic sanctions have proven useless and nuclear reactors are being built in Iran as we speak. New evidence acquired by the International Atomic Energy Agency proves that Iran is on the verge of building a nuclear arsenal.

Nuclear Iran will be a threat to its neighbors and to world peace. In Iran itself we see the vision the Iranian regime has for the entire region: Iranians suffer brutal governance, a paralyzed economy, and the denial of basic human rights. That is the future the Iranian regime is offering to the people of the Middle East. A nuclear Iran will not hesitate before attacking its neighbors in order to impose this dark vision upon them.

Because diplomacy and economic sanctions have failed to put an end to Iran's nuclear ambitions, the United Nations Security Council has no choice but to authorize a coalition air strike to stop the construction of nuclear facilities in Iran, unless the regime immediately dismantles its nuclear program and allows verification by $\mathrm{UN}$ inspectors.

Today, the United Nations Security Council is giving an ultimatum to the Iranian government: stop the construction of nuclear facilities or face military consequences. The Security Council will allow Iran one more month: if by the end of this term the Council's demand is not met, a coalition air strike will be launched in order to destroy all nuclear facilities in Iran, to enforce an international resolution, and to bring a better democratic future to the Middle East. As a loyal member of the United Nations Security Council, the United States will be part of a coalition air strike in Iran." 
States unilaterally or by the UN, whether the goal of the ultimatum was to protect the nation from an aggressor or to comply with a more internationalist agenda, or whether the expected air strike would be launched by the U.S. Air Force alone or by a coalition force.

In the second step of the experiment, all participants were asked to complete a questionnaire that inquired about their feelings and attitudes toward the government of Iran and the possibility of an air strike in Iran as well as their general attitudes toward the United States and its international relationships. ${ }^{4}$ Other questions gathered supplemental information on the demographic characteristics of respondents and their exposure to news reports. Responses to all but a few questions were measured on a 6-point Likert scale.

\section{Data and Analytical Approach}

The experiment was administered from June 24 to June 30, 2011, by YouGov, an Internet-based polling firm. YouGov interviewed a sample of 558 respondents that was representative of the U.S. population in terms of core demographic variables. ${ }^{5}$ Interviewees were randomly assigned to the control and test groups (the demographic characteristics of the sample are presented in the supplementary material).

To reduce potential measurement errors, this study employed the standard practice of treating attitudes, sentiments, and emotions as latent variables-underlying common factors detected by sets of items. Table 2 presents the questions that composed each scale. Support for an air strike in Iran was measured by three survey items: the first asked about general support, whereas the other two asked about support under the conditions of a substantial number of casualties to the U.S. Air Force and damage to the U.S. economy due to the air strike. Therefore, individuals scored high on the composite measure if they reported a high level of support without regard for the costs of the strike.

The next two scales measured two aspects of national identification (both were created by Kosterman and Feshbach [1989], and both are commonly used by political psychologists). The National Hubris Scale included three items: (1) "In view of America's moral and military superiority, it is only right that we should have the biggest say in international policies"; (2) "Other countries should try to make their governments as much like ours as possible"; and (3) "The most important thing for any foreign policy program of our government is to see to it that the interests of the U.S. are served." The Patriotism Scale, which measures love of and pride in the nation and the nation-state, included four items: (1) "I am proud to be an American"; (2) "I love the United States"; (3) "The fact that I am an American is an important part of my identity"; and (4) "I feel great when I see the American flag flying." Table 2 includes three additional scales used to test alternative hypotheses: assessment of the military operation's chances of success, anger about Iran's nuclear program, and fear of Iran's nuclear program.

Data analysis was conducted in three steps. First, factor analysis conducted via Stata was used to determine which items from the questionnaire should be included in the next steps of model estimation. Factor analysis confirmed that 
Table 2: Survey Items, Scales, and Internal Consistency Scores

\begin{tabular}{|c|c|c|}
\hline Survey Item & Scale & Cronbach's $\alpha$ \\
\hline $\begin{array}{l}\text { 1: I support an air strike in Iran. } \\
\text { 2: I support an air strike in Iran even if it means that } \\
\text { the U.S. air force might suffer a substantial number of } \\
\text { casualties. } \\
\text { 3: I support an air strike in Iran even if this might hurt } \\
\text { the American economy. }\end{array}$ & Support for air strike & 0.92 \\
\hline $\begin{array}{l}\text { 4: In view of America's moral and military superiority, } \\
\text { it is only right that we should have the biggest say in } \\
\text { international policies. } \\
\text { 5: Other countries should try to make their governments } \\
\text { as much like ours as possible. } \\
\text { 6: The most important thing for any foreign policy is to } \\
\text { see to it that the interests of the U.S. are served. }\end{array}$ & National hubris & 0.74 \\
\hline $\begin{array}{l}\text { 7: I am proud to be American. } \\
\text { 8: I love the United States. } \\
\text { 9: Being American is an important part of my identity. } \\
\text { 10: I feel proud when I see the American flag flying. }\end{array}$ & Patriotism & 0.91 \\
\hline
\end{tabular}

11: As far as I can tell, an air strike in Iran is likely to Assessment of success chances 0.90 succeed.

12: I believe that an air strike in Iran is likely to fail.

13: I believe that an air strike in Iran will achieve its goals.

14: I feel confident that an air strike in Iran will achieve its goals.

15: Thinking about the Iranian Government makes me feel angry.

Anger

0.93

16: Thinking about the Iranian Government makes me feel irritated.

17: I feel annoyed by the Iranian Government.

18: When thinking about the Iranian Government, I feel disgusted.

19: Thinking about the nuclear program of Iran scares me.

20: Thinking about the nuclear program of Iran makes me feel nervous.

21: Thinking about the nuclear program of Iran makes me feel worried.

22: Thinking about the nuclear program of Iran makes me feel anxious.

Note: The order of items was constantly randomized in the survey. 


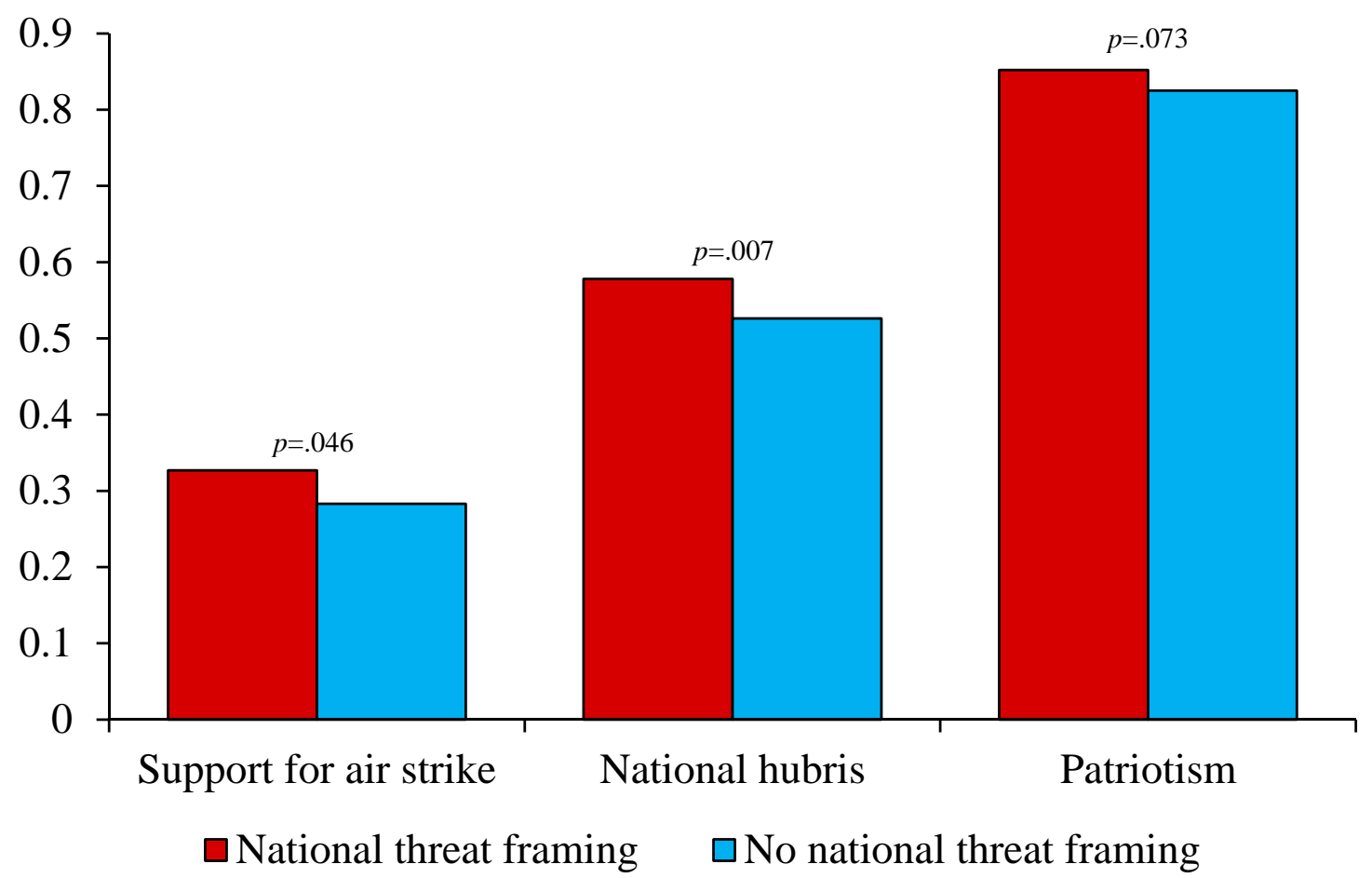

Figure 1: Effects of national threat framing on outcome scales $(N=558) . p$-Values are for the differences in means, based on independent samples $t$-test.

conceptually different latent variables-for example, national hubris and support for military action - were empirically distinguishable. Second, hypothesis testing was conducted in Stata via structural equation modeling (SEM), which allowed me to test whether the effect of exposure to national threat rhetoric on level of support for military operations was mediated by national hubris. In addition, I used SEM to test competing arguments that are introduced later. ${ }^{6}$

Because no statistically significant differences were found between the average scores of the control and the internationalist-framing groups in any part of the analysis, in the following presentation and discussion of findings, I combine these two groups and contrast their combined scores with the scores of the group that was exposed to the national threat rhetoric (for the distributions of survey questions measuring national hubris and support for military action in the three framing groups, see Supplementary Figures S1 and S2). ${ }^{7}$

\section{Findings and Discussion}

Figure 1 presents the results of an initial test of the effects of the national threat rhetoric on (1) the latent variable that measures support for an air strike in Iran 


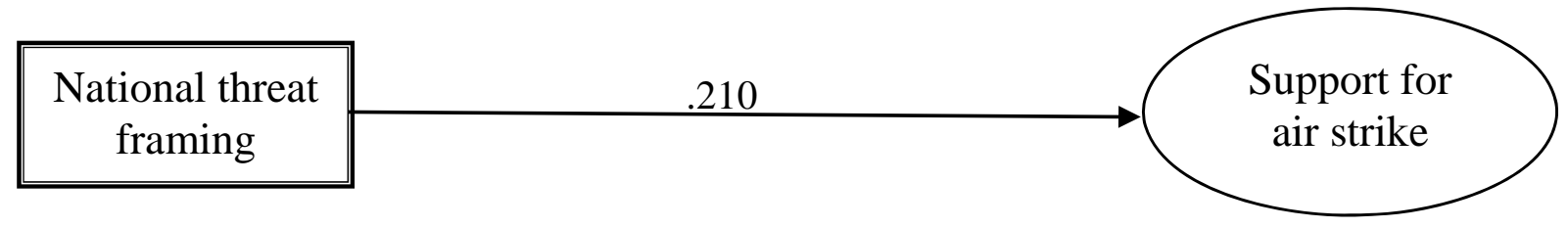

Chi2 (model vs. saturated) $=0.5(2), p=.774 ;$ RMSEA $<.001 ;$ CFI=1.000; SRMS $=.004$

Figure 2: Direct effect of national threat framing on support for an air strike.

and (2) the latent variables that measure aspects of national identification. Each pair of bars shows the results for one scale, and scores are shown separately for participants who were exposed to the national threat rhetoric and participants who were either exposed to the internationalist framing or assigned to the control group.

The first set of bars on the left shows that participants in the national threat group had significantly higher mean scores on the support scale $(p=0.046) .{ }^{8}$ The next two sets of bars show that the difference between the mean scores of the national threat group and the comparison group is considerably larger for the variable measuring national hubris (about 10 percent) than for the variable measuring patriotism (about 3 percent) and is statistically significant only for the former.

Random assignment to control and test groups makes the possibility that the preceding findings represent unbalanced assignment very unlikely. Nonetheless, in a subsequent analysis (results not shown), I tested this possibility by taking two additional steps. First, I checked whether assignment to groups was associated with the following characteristics of individuals: gender, age, education, race/ethnicity, partisan identification, ideology, and knowledge about Iran. None of these variables had a statistically significant relationship with group assignment. Second, I reestimated the mean differences reported in Figure 1 while holding the demographic variables constant. The findings were similar to those reported in Figure 1.Taken together, these tests suggest that it is very likely that the higher mean scores of the national threat group on the variables measuring national hubris and support for an air strike were due to exposure to the national threat rhetoric.

Next, in Figures 2 and 3, I estimated SEMs to test whether the effect of exposure to the national threat rhetoric on the level of support for the air strike was mediated by national hubris. ${ }^{9}$ Using conventional SEM notation, observed variables are represented by rectangles and latent variables are represented by ovals. Each latent variable was estimated via a system of regression equations connecting the variable to three to five survey questions; to keep the graphical presentation as succinct as possible, the survey questions and their individual coefficients are not presented (the supplementary material reports the survey questions and their coefficients). Solid arrows represent regression coefficients that are statistically significant at the 0.05 level or less, and dashed arrows represent coefficients that are not statistically significant at this level.

The results suggest the presence of a mediating influence: the effect of the national threat rhetoric on support for an air strike, which was small but statistically 


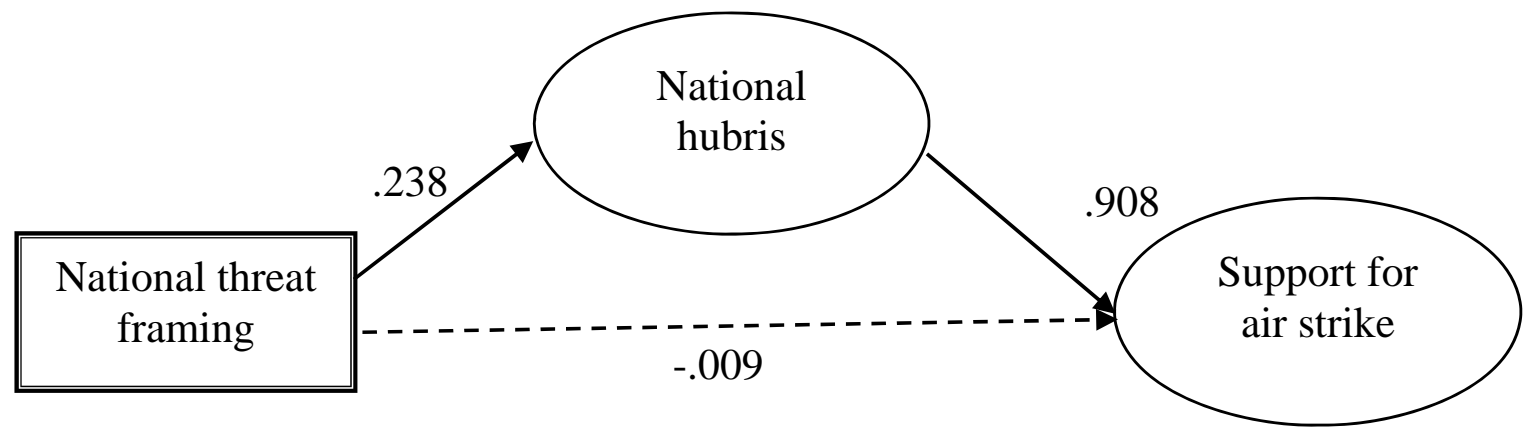

Chi2 (model vs. saturated)=24.6(12), $p=.017$; RMSEA=.043; CFI=.993; SRMS=.019

Bias-corrected $95 \%$ confidence interval for indirect path: .053 to .379

Figure 3: Effect of national threat framing on support for an air strike mediated by national hubris.

significant in the first model, declined and was no longer statistically significant in the models that included national hubris. To check the statistical significance of the indirect effect, I used the bootstrapping procedure recommended by Hayes (2009) with 5,000 repetitions, which produced a bias-corrected 95\% confidence interval with a lower bound of 0.053 and an upper bound of $0.379 .{ }^{10}$ The mediation effect is therefore statistically significant. To further check the robustness of findings, I added to each regression equation a set of control variables pertaining to respondents' gender, education, age, ethnicity/race, religion, religiosity, partisan identification, and ideology. All coefficients reported above maintained size and statistical significance (see Supplementary Table S1).

The next step was adding variables associated with prominent theoretical arguments about popular support for military actions in the United States. The dominant approach to popular support for military actions is based on the rational choice paradigm. Americans are more likely to support wars, proponents of this perspective argue, when they believe that their goals will likely be achieved at a tolerable cost in American lives (e.g., Eichenberg 2005; Gelpi, Feaver, and Reifler 2006; Jentleson and Britton 1998). In contrast to the rationalist approach, political psychologists have recently highlighted the role of emotions in motivating individuals to support military actions and the presidents who order them (Aday 2010; Lambert et al. 2010; Schildkraut 2002). Specifically, several studies point to the contrasting effects of fear and anger: whereas fear is often negatively associated with support for military action, because individuals who experience a significant level of fear tend to be risk averse, anger motivates support for military actions, because being angry drives individuals toward action and risk taking (Huddy et al. 2005; Lerner et al. 2003; Skitka et al. 2006).

To check whether greater support in the national threat group for an air strike in Iran was due to assessment of success chances and cost or by increased anger and reduced fear, Figures 4 and 5 compare the scores of participants in the national threat group on indicators of these arguments to the scores of the rest of the sample. The findings show no statistically significant differences between the groups in the 


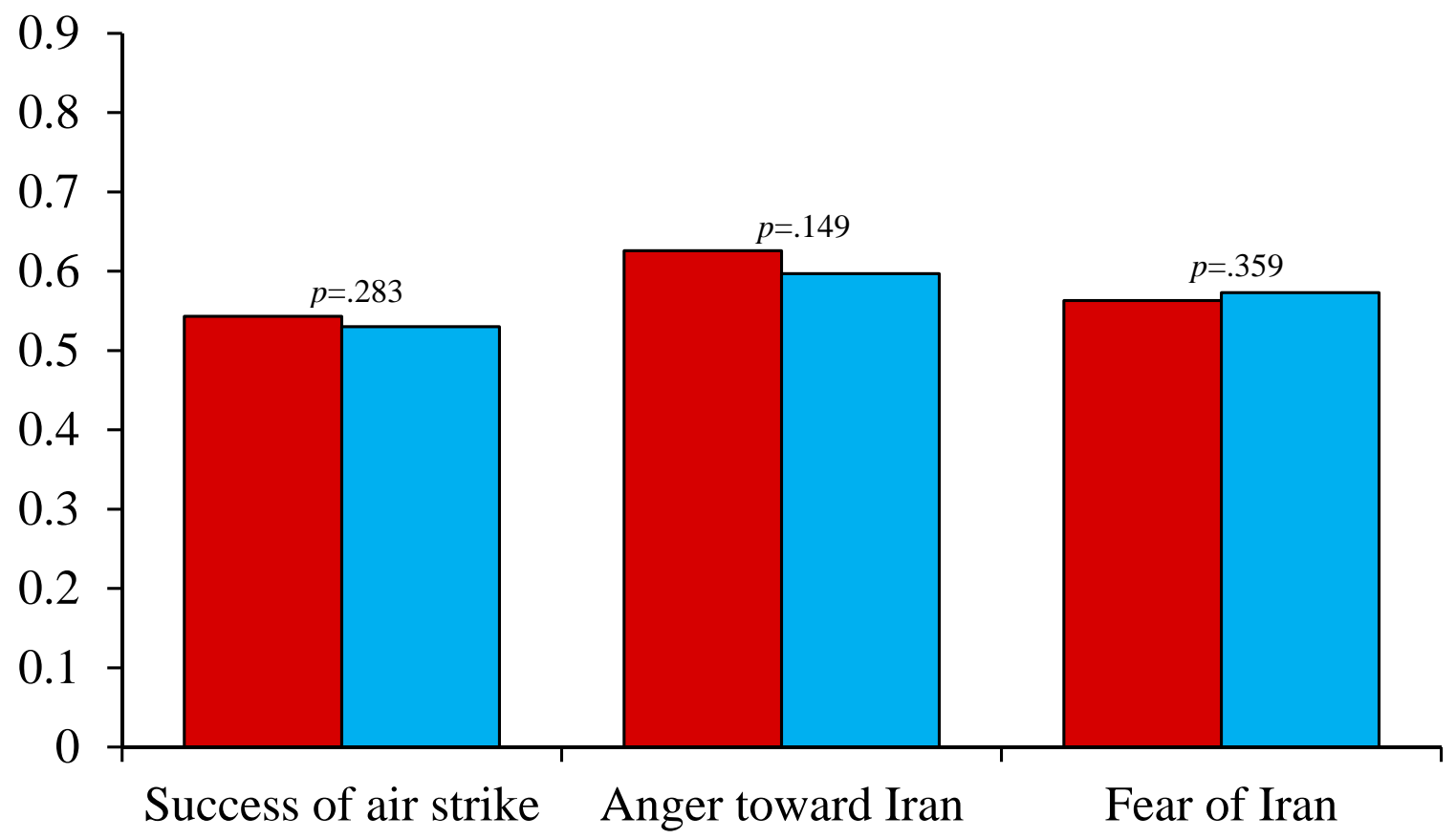

$\square$ National threat framing $\quad \square$ No national threat framing

Figure 4: Effects of national threat framing on scales associated with competing explanations $(N=558)$. $p$-Values are for the differences in means, based on independent samples $t$-test.

variables that serve as indicators of the "rational actor" argument (participant's assessment of success chances of an air strike, its expected duration, and cost in American lives) or in the scales that measure anger about and fear of Iran's nuclear program.

These findings surely do not suggest that changes in assessment of success chances and costs or emotional shifts never have significant effects on public opinion. The manipulation used in this study was not designed for testing the competing arguments. However, including these variables in the analysis is necessary to test the robustness of the findings that support my own argument. Figure 6 presents the results of a SEM that includes both the national hubris variable and the variables associated with competing arguments.

The results show that the national threat rhetoric increased national hubris but had no effect on variables associated with competing arguments. Figure 6 does show that support for military action is likely to be higher if a person is angry about the enemy's actions, assesses that a military action will likely succeed, and expects few American casualties. However, it is important to notice that (1) the association between national hubris and support for military action remains statistically significant even when the model controls for the mechanism specified 


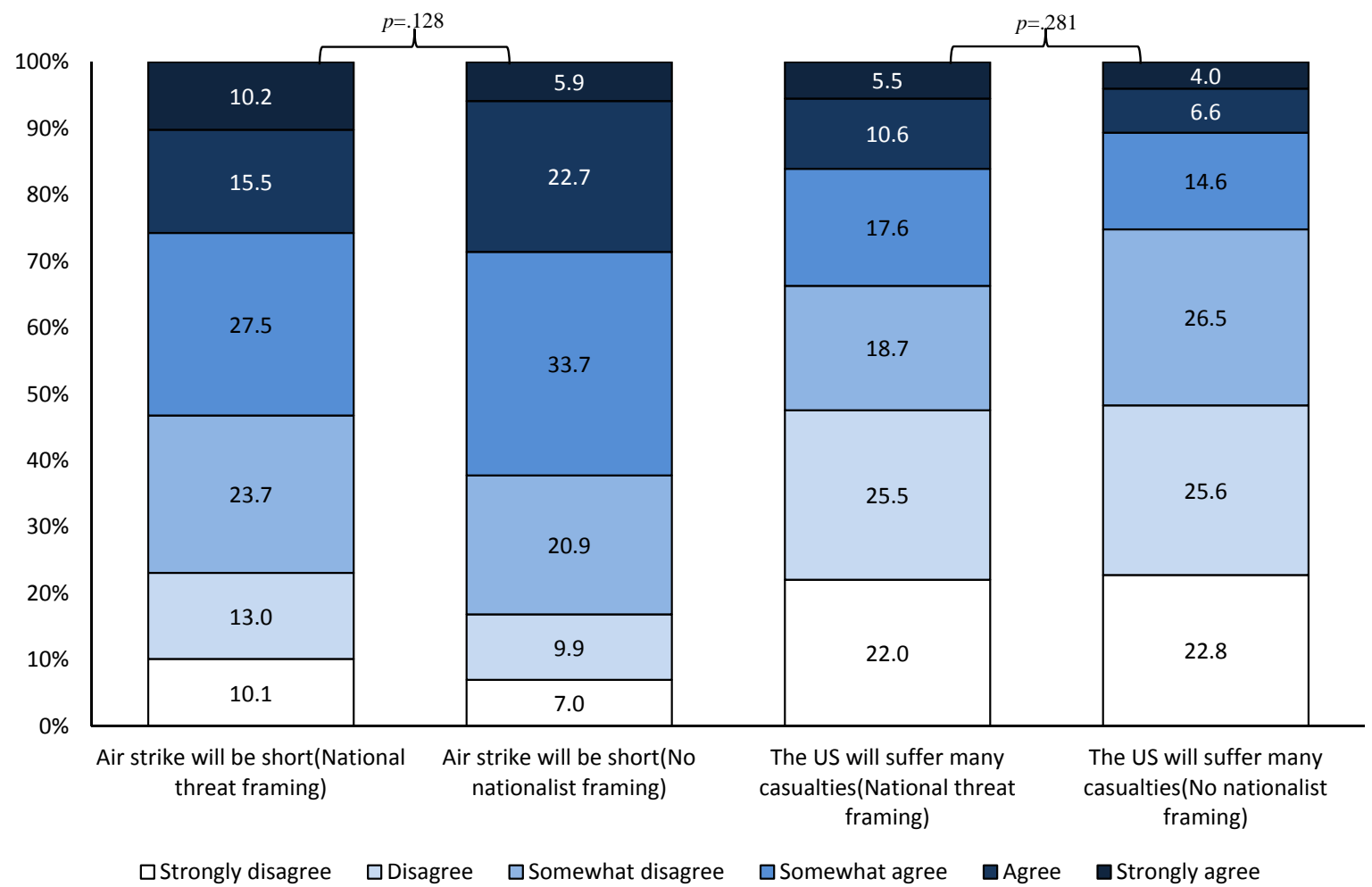

Figure 5: Effects of national threat framing on assessment of duration of air strike and number of U.S. casualties $(N=558)$. $p$-Values are based on Wilcoxon-Mann-Whitney nonparametric test of differences between independent samples.

in other theoretical arguments and (2) focusing on the change in levels of support in response to the manipulation, we see that that change was mediated by national hubris and not by the other variables in the model.

To summarize, SEM results provide substantial evidence for the hypothesized process: the national threat rhetoric activated national hubris about the expected air strike in Iran, which in turn made participants more likely to support the air strike.

\section{Conclusion}

The experimental results demonstrate that the framing of military action as a response to threats to the nation and the nation-state activated a sentiment of national superiority that then led to higher levels of support for an air strike in Iran and thus showed that within the context of a seemingly real international conflict, there were causal links between an official rhetoric that highlights national threats, national hubris, and attitudes toward military action. Although this study is a considerable improvement over previous studies, which have used either ordinary survey data or laboratory experiments, it is not without limitations. First, the sample included only those individuals who agreed to participate, which raises the 




Notes:

Chi2 (model vs. saturated)=1790(180), $p<.001$; RMSEA=.127; CFI=.883; SRMS=.271

Bias-corrected 95\% confidence interval for indirect path through national hubris: .019 to .140

Figure 6: Author's argument versus competing arguments.

issue of selectivity. However, the selectivity problem is less severe in this study than in laboratory experiments, which are usually based on small convenience samples. As the supplementary material shows, the sample was fairly representative of the U.S. population. In addition, selectivity bias was reduced because participants were not told that they were part of an experiment (Mutz 2011:143).

Second, although the experiment measured the effect of a treatment given exposure, it did not estimate the likelihood of exposure (during a real security crisis, it is likely that most citizens would be exposed to a presidential address concerning the crisis, but that assumption was not tested in this study). Third, during real security crises, individuals are exposed to elite framing multiple times and often process the information by deliberating with others; however, this experiment exposed participants to elite framing only once, and although deliberation was possible, the setting did not encourage it. Fourth, the experiment did not test the duration of the framing effects, which may be short-lived.

Despite its limitations, this study makes a significant contribution. In previous research that analyzed cross-sectional survey data, high or low levels of national hubris were assumed to be a fixed trait of individuals. In contrast, my study 
shows that national hubris may increase under perceived threats to the nation and that this mechanism is associated with increased support for military action. This contribution is twofold. At the theoretical level, this study applied a smallgroup social psychological mechanism to a large-group phenomenon: studies on individual behavior in small groups have shown that protecting the status of the group from external threats often motivates individuals to act in ways that enhance the group's value relative to other groups. This article has argued that the same mechanism operates at the national level, if and when an international conflict motivates individuals to protect the prestige of the nation. At the empirical level, this study revealed the specific mechanism by which increased identification with the nation affects political attitudes: using a controlled experiment, the study showed that increased national hubris affected support for war. The extent to which this mechanism can be generalized beyond the American case is a question for future research. Appealing to sentiments of national superiority may be most likely to succeed in countries in which popular nationalism is coupled with militaristic attitudes. I speculate that an association between nationalism and militarism is more likely to occur in two types of countries: those that have fought many wars and were usually victorious, both militarily and politically (e.g., France and Britain), and those in which the military is strongly embedded organizationally in the population at large (e.g., Israel). These speculations can serve as hypotheses for future research.

\section{Notes}

1 Furthermore, two recent studies that did address this issue reached differing conclusions: whereas Kohut and Stokes (2006) found that nationalism does not play a significant role in the formation of attitudes toward international issues, Gries (2014) reported positive and strong correlations between measures of nationalism and "measures of support for the use of military force and overall desire for tougher foreign policy" (p. 119).

2 Other political psychologists have added that national hubris also rationalizes the use of force, because it places the entire blame for the conflict and its negative consequences on a morally inferior enemy (Roccas, Klar, and Liviatan 2006).

3 The speaker is a public relations professional, and the statement was recorded in a professional studio.

4 No pretest was administered, because doing so might have revealed the intentions of the study.

5 At the time of the study, YouGov's matching frame used the 2005-7 American Community Survey's three-year estimates for gender, age, race, Hispanic origin, education level, family income, marital status, number of children under 18, employment status, citizenship, state residence, and metropolitan area. YouGov employed a five-way stratified selection from the panel, matching panel respondents on State $\times$ Age $\times$ Race $\times$ Gender $\times$ Education strata.

6 In SEM, the estimation of latent variables is model dependent and sample dependent. Therefore, as an additional step (results not shown), I repeated the analysis with latent variables measured as the mean score of its observed indicators. The conclusions from the two methods are the same.

7 However, to verify that the activation of national hubris actually occurred, I compared the exposed group to each of the other two groups. The comparison with the internation- 
alist framing group allowed me to verify that differences between "test" and "control" groups were not due to the exposure or lack of exposure to a presidential statement. The comparison with the control (i.e., "no framing") group allowed me to verify that the observed effects were due to activated national hubris in the national threat framing group (as hypothesized) rather than reduced national hubris in the internationalist framing group.

8 Although the effect of national threat framing on support for an air strike could possibly represent an ideological divide between "unilateralists" and "multilateralists" (Hinckley 1988; Holsti 1992), two findings suggest that that was not the case: (1) the average level of support for the air strike was nearly identical whether participants thought that the United States was going to attack Iran unilaterally or foresaw a coalition air strike and (2) the effect of nationalist attitudes on support for an air strike was of similar size and statistical significance when the analysis was run separately for participants who believed that the United States was going to act unilaterally and participants who foresaw multilateral action.

9 Because support for an air strike is a nonnegative skewed variable, all models were reestimated via generalized linear regression with log link, as recommended by Cox et al. (2007). The conclusions were the same as the conclusions from using ordinary least squares used in SEMs throughout the article.

10 This procedure is superior to other tests of mediation because it does not assume that indirect effects are normally distributed (as the Sobel test does).

\section{References}

Aday, Sean. 2010. "Leading the Charge: Media, Elites, and the Use of Emotion in Stimulating Rally Effects in Wartime." Journal of Communication 60:440-65. http://dx. doi .org/10. $1111 / j .1460-2466.2010 .01489 . x$

Bonikowski, Bart and Paul DiMaggio. Forthcoming. "Varieties of Popular American Nationalism." American Sociological Review

Bourdieu, Pierre. 2000. Pascalian Meditations. Stanford, CA: Stanford University Press.

Brader, Ted. 2006. Campaigning for Hearts and Minds: How Emotional Appeals in Political Ads Work. Chicago: University of Chicago Press.

Brooks, Deborah Jordan and Benjamin A. Valentino. 2011. "A War of One's Own: Understanding the Gender Gap in Support for War." Public Opinion Quarterly 75:270-86. http://dx.doi.org/10.1093/poq/nfr005

Brubaker, Rogers. 2004. Ethnicity without Groups. Cambridge, MA: Harvard University Press. http://dx.doi.org/10.1017/cbo9780511489235.004

Cox, Nicholas J., Jeff Warburton, Alona Armstrong, and Victoria J. Holliday. 2007. "Fitting Concentration and Load Rating Curves with Generalized Linear Models." Earth Surface Processes and Landforms 33(1):25-39. http://dx . doi .org/10.1002/esp. 1523

de Figueiredo, Rui J. P. and Zachary Elkins. 2003. "Are Patriots Bigots? An Inquiry into the Vices of In-Group Pride." American Journal of Political Science 47:171-88. http://dx. doi . org/10.1111/1540-5907.00012

Dekker, Henk, Darina Malova, and Sander Hoogendoorn. 2003. "Nationalism and Its Explanations." Political Psychology 24(2):345-75. http://dx.doi .org/10.1111/0162-895X. 00331 
Druckman, James N., Donald P. Green, James H. Kuklinski, and Arthur Lupia. 2006. "The Growth and Development of Experimental Research in Political Science." American Political Science Review 100:627-35. http://dx . doi .org/10.1017/S0003055406062514

Eichenberg, Richard C. 2005. “Victory Has Many Friends: US Public Opinion and the Use of Military Force, 1981-2005." International Security 30:140-77. http://dx . doi .org/10 . $1162 / 0162288054894616$

Elias, Norbert. [1956] 1998. "Involvement and Detachment." Pp. 85-91 in The Norbert Elias Reader, edited by Johan Goudsblom and Stephen Mennell. Oxford: Blackwell.

Ellemers, Naomi, Russell Spears, and Bertjan Doosje. 2002. "Self and Social Identity." Annual Review of Psychology 53:161-86. http://dx.doi.org/10.1146/annurev.psych . 53.100901 .135228

Feinstein, Yuval. Forthcoming. "Rallying Around the President: When and Why Do Americans Close Ranks behind Their Presidents during International Crisis and War?" Social Science History. http://dx. doi .org/10.1017/ssh.2016.5e

Finlayson, Alan. 1998. "Psychology, Psychoanalysis and Theories of Nationalism." Nations and Nationalism 4:145-62. http://dx.doi.org/10.1111/j.1354-5078.1998.00145.x

Gelpi, Christopher, Peter D. Feaver, and Jason Reifler. 2006. "Success Matters: Casualty Sensitivity and the War in Iraq." International Security 30:7-46. http://dx. doi .org/10. 1162/isec. 2005.30.3.7

Greenfeld, Liah. 2006. Nationalism and the Mind: Essays on Modern Culture. Oxford: Oneworld.

Gries, Peter H. 2014. The Politics of American Foreign Policy: How Ideology Divides Liberals and Conservatives over Foreign Affairs. Stanford, CA: Stanford University Press.

Hayes, Andrew F. 2009. "Beyond Baron and Kenny: Statistical Mediation Analysis in the New Millennium." Communication Monographs 76(4):408-20. http://dx.doi.org/10. $1080 / 03637750903310360$

Herrmann, Richard K., Pierangelo Isernia, and Paolo Segatti. 2009. "Attachment to the Nation and International Relations: Dimensions of Identity and Their Relationship to War and Peace." Political Psychology 30:721-54. http://dx. doi .org/10.1111/j .1467-9221. 2009.00723.x

Hinckley, Ronald H. 1988. "Public Attitudes toward Key Foreign Policy Events." Journal of Conflict Resolution 32(2):295-318. http://dx.doi.org/10.1177/0022002788032002003

Holsti, Ole R. 1992. "Public Opinion and Foreign Policy: Challenges to the AlmondLippmann Consensus Mershon Series: Research Programs and Debates." International Studies Quarterly 36:439-66. http: //dx.doi.org/10.2307/2600734

Huddy, Leonie, Stanley Feldman, Charles Taber, and Gallya Lahav. 2005. “Threat, Anxiety, and Support of Antiterrorism Policies." American Journal of Political Science 49:593-608. http://dx.doi.org/10.1111/j.1540-5907.2005.00144.x

Huddy, Lenonie and Nadia Khatib. 2007. “American Patriotism, National Identity, and Political Involvement." American Journal of Political Science 51(1):53-77. http://dx . doi . org/10.1111/j.1540-5907.2007.00237.x

Jentleson, Bruce W. and Rebecca L. Britton. 1998. "Still Pretty Prudent: Post-Cold War American Public Opinion on the Use of Military Force." Journal of Conflict Resolution 42:395-417. http://dx.doi.org/10.1177/0022002798042004001

Kaufmann, Chaim. 2004. "Threat Inflation and the Failure of the Marketplace of Ideas: The Selling of the Iraq War." International Security 29:5-48. http://dx.doi.org/10.1162/ 0162288041762940 
Kohn, Hans. 1944. The Idea of Nationalism: A Study in Its Origins and Background. New York: Macmillan.

Kohut, Andrew and Bruce Stokes. 2006. America against the World: How I Are Different and Why I Are Disliked. New York: Henry Holt.

Kosterman, Rick and Seymour Feshbach. 1989. "Toward a Measure of Patriotic and Nationalistic Attitudes." Political Psychology 10:257-74. http://dx.doi.org/10. 2307/3791647

Lambert, Alan J., Laura D. Scherer, John Paul Schott, Kristina R. Olson, Rick K. Andrews, Thomas C. O'Brien, and Alison R. Zisser. 2010. "Rally Effects, Threat, and Attitude Change: An Integrative Approach to Understanding the Role of Emotion." Journal of Personality and Social Psychology 98:886-903. http://dx . doi .org/10.1037/a0019086

Lerner, Jennifer S., Roxana M. Gonzalez, Deborah A. Small, and Baruch Fischhoff. 2003. "Effects of Fear and Anger on Perceived Risks of Terrorism: A National Field Experiment." Psychological Science 14:144-50. http://dx.doi.org/10.1111/1467-9280.01433

Lipset, Seymour Martin. 1990. Continental Divide: The Values and Institutions of the United States and Canada. New York: Routledge.

McLaughlin, Neil. 1996. "Nazism, Nationalism, and the Sociology of Emotions: Escape from Freedom Revisited." Sociological Theory 14(3):241-61. http://dx.doi.org/10.2307/ 3045388

Mutz, Diana C. 2011. Population-Based Survey Experiments. Princeton, NJ: Princeton University Press. http://dx.doi.org/10.1515/9781400840489

Nincic, Miroslav. 1997. "Loss Aversion and the Domestic Context of Military Intervention." Political Research Quarterly 50:97-120. http://dx.doi.org/10.1177/ 106591299705000105

Roccas, Sonia, Yechiel Klar, and Ido Liviatan. 2006. “The Paradox of Group-Based Guilt: Modes of National Identification, Conflict Vehemence, and Reactions to the In-Group's Moral Violations." Journal of Personality and Social Psychology 91(4):698-711. http://dx . doi.org/10.1037/0022-3514.91.4.698

Schildkraut, Deborah J. 2002. “The More Things Change ... American Identity and Mass and Elite Responses to 9/11." Political Psychology 23:511-35. http://dx.doi .org/10.1111/ 0162-895X.00296

Schildkraut, Deborah J. 2011. Americanism in the Twenty-First Century: Public Opinion in the Age of Immigration. New York: Cambridge University Press.

Skitka, Linda J., Christopher W. Bauman, Nicholas P. Aramovich, and G. Scott Morgan. 2006. "Confrontational and Preventative Policy Responses to Terrorism: Anger Wants a Fight and Fear Wants 'Them' to Go Away.” Basic and Applied Social Psychology 28:375-84. http://dx.doi.org/10.1207/s15324834basp2804_11

Snyder, Jack and Erica D. Borghard. 2011. “The Cost of Empty Threats: A Penny, Not a Pound." American Political Science Review 105:437-56. http://dx. doi .org/10.1017/ S000305541100027X

Willer, Robb. 2004. "The Effects of Government-Issued Terror Warnings on Presidential Approval Ratings." Current Research in Social Psychology 10:1-12.

Worchel, Stephen and Dawna Coutant. 1997. "The Tangled Web of Loyalty: Nationalism, Patriotism, and Ethnocentrism." Pp. 190-210 in Patriotism in the Life of Individuals and Nations, edited by Daniel Bar-Tal and Ervin Straub. Chicago: Nelson-Hall.

Zelditch, Morris, Jr. 2007. “The External Validity of Experiments That Test Theories." Pp. 87-112 in Laboratory Experiments in the Social Sciences, edited by Murray Webster Jr. and Jane Sell. Boston: Academic Press/Elsevier. 
Acknowledgements: The author is grateful to the National Science Foundation for providing the funding for this research. The author also thanks Terece Bell, Jeremy Broekman, Philippe Duhart, Jennifer Eggerling-Boeck, Vered Kraus, Robert D. Mare, Zeynep Ozgen, David O. Sears, Andreas Wimmer, and Meir Yaish for their help and advice regarding theory, research design, and manuscript preparation. Previous versions of the article were presented at the annual meetings of the American Sociological Association (2012), the Association for the Study of Nationalities (2012), and the Israeli Political Science Association (2013). I thank conveners and audiences for stimulating comments and challenging criticisms.

Yuval Feinstein: Department of Sociology and Anthropology, University of Haifa. E-mail: fyuval@soc.haifa.ac.il. 